\title{
Effect of Nereis diversicolor density on the erodability of estuarine sediment
}

\author{
John Widdows*, Mary D. Brinsley, Nick D. Pope \\ Plymouth Marine Laboratory, Prospect Place, The Hoe, Plymouth, PL1 3DH, UK
}

\begin{abstract}
Nereis diversicolor is a widely distributed estuarine polychaete worm that is particularly abundant in the mid to upper parts of estuaries. Laboratory annular flumes were used to study the effects of $N$. diversicolor density ( 0 [control], 100, 300, 1000, 3000 individuals $\mathrm{m}^{-2}$ ) on erodability of cohesive muddy sediments. At the highest densities (1000 and 3000 ind. $\mathrm{m}^{-2}$ ) there was evidence of active sediment resuspension under low current speeds $\left(U=0.05 \mathrm{~m} \mathrm{~s}^{-1}\right)$. In response to a step-wise increase in $U$ there was a density-dependent increase in the sediment mass eroded $\left(\mathrm{g} \mathrm{m}^{-2}\right)$. At 3000 individuals $\mathrm{m}^{-2}$ and at a flow of $0.4 \mathrm{~m} \mathrm{~s}^{-1}$, sediment erosion increased 37 -fold compared to the control. Erosion thresholds representing the onset of sediment resuspension (Type 1a erosion) were low and similar for all worm densities, including the control (critical erosion velocity $U_{\text {crit }}=0.11$ to $0.12 \mathrm{~m} \mathrm{~s}^{-1}$; critical bed shear stress for erosion $\left[\tau_{\mathrm{e}}\right]=0.02$ to $\left.0.036 \mathrm{~Pa}\right)$. However, at the lower densities $(0$ to 300 ind. $\mathrm{m}^{-2}$ ) there was little bed erosion until $U=0.4$ to $0.45 \mathrm{~m} \mathrm{~s}^{-1}$ (bed shear stress $=0.16$ to $0.2 \mathrm{~Pa}$ ). The burrowing and surface feeding activity of the polychaete destabilised the bed and increased sediment erodability as a function of worm density. The influence of $N$. diversicolor $\left(300\right.$ ind. $\mathrm{m}^{-2}$ ) on sediment erosion and deposition during sinusoidal tidal current cycles $\left(0.05\right.$ to $\left.0.35 \mathrm{~m} \mathrm{~s}^{-1}\right)$ was also studied in the flumes. There was a consistent cycle of erosion and deposition with worms inducing $\sim 2$-fold higher erosion and deposition rates following an erosion threshold of $U \geq 0.11 \mathrm{~m} \mathrm{~s}^{-1}\left(\tau_{\mathrm{e}}=0.02 \mathrm{~Pa}\right)$ and a deposition threshold of $U \leq 0.26 \mathrm{~m} \mathrm{~s}^{-1}\left(\tau_{\mathrm{d}}=0.07 \mathrm{~Pa}\right)$. Maximum erosion and deposition rates occurred at $0.25 \mathrm{~m} \mathrm{~s}^{-1}$ and $0.11 \mathrm{~m} \mathrm{~s}^{-1}$, respectively. The results suggest that $N$. diversicolor can make a significant contribution to increased erosion of fine intertidal muddy sediments and to the overall turbidity in the upper estuary.
\end{abstract}

KEY WORDS: Nereis diversicolor $\cdot$ Sediment $\cdot$ Erosion $\cdot$ Deposition $\cdot$ Currents $\cdot$ Tidal cycles

\section{INTRODUCTION}

Nereis diversicolor (Hediste diversicolor) is a widely distributed and abundant estuarine polychaete, reaching particularly high densities in the mid-section of estuaries where salinities typically range from 10 to 25 psu. Densities in the Tamar estuary, in the southwestern UK, are typical of those found in temperate estuaries (Ait Alla et al. 2006), ranging from $\sim 100 \mathrm{~m}^{-2}$ in the lower Tamar to maximum densities of $3600 \mathrm{~m}^{-2}$ in the middle section of the Tamar (Spooner \& Moore 1940, Warwick \& Gee 1984). Similar maximum densities have also been reported in the Authie and Seine estuaries, France (Gillet et al. 2008) and in Denmark's shallow Odense fjord (Vedel 1998). N. diversicolor live in semi-permanent burrows that provide refuge from predators and partially isolate them from extreme environmental changes (e.g. salinity, temperature, dehydration during low-tide air exposure). They have a range of feeding behaviours, including deposit feeding, grazing on microphytobenthos and macrophytes, filter feeding, scavenging and predation on other macro- and meiofauna (Vedel \& Riisgård 1993, Paramor \& Hughes 2004, Engelsen \& Pihl 2008).

Ecosystems are generally controlled and organised by a small set of organisms and abiotic processes that engineer and structure the landscape or substrate at different scales (Lawton \& Jones 1995). The physical 
and chemical properties of marine sediments are modified by biota (Rhoads \& Young 1970). More specifically, the stability of intertidal estuarine sediments is influenced by a few key biota acting as bio-stabilisers or bio-destabilisers (Widdows \& Brinsley 2002). There is some controversy about whether Nereis diversicolor is a bio-stabiliser or destabiliser of sediments. Some researchers consider this species a stabiliser, based on its influence on sediment shear strength (Meadows \& Tait 1989, Meadows et al. 1990). However, this geotechnical property is not directly related to erosion potential of surface sediments. Others have provided evidence that the species functions as a destabiliser, mainly through correlations between $N$. diversicolor density and sediment erodability in field studies (de Deckere et al. 2001, Widdows et al. 2006). To date, the only flume study to investigate the influence of $N$. diversicolor on sediment erodability (Fernandes et al. 2006) produced rather equivocal results, with no consistent or marked impact on sediment stability. The study by Fernandes et al. (2006) was performed after a period of $20 \mathrm{~d}$ consolidation of sediment in the laboratory, over a limited range of densities (450 to 1200 ind. $\mathrm{m}^{-2}$ ), and under conditions inducing a high worm mortality (up to $69 \%$ ), perhaps due to insufficient aeration of overlying water.

The main aims of our flume study were therefore to: (1) quantify the influence of Nereis diversicolor density on the erodability of cohesive muddy sediments; (2) investigate the effect of $N$. diversicolor on sediment erosion and deposition during sinusoidal tidal-cycles in current speeds; (3) examine whether experimental evidence supports the significant correlations between $N$. diversicolor density and sediment erodability previously recorded in field studies; and (4) assess the contribution that this polychaete may make to destabilising estuarine mudflats and enhancing sediment resuspension by currents and waves.

\section{MATERIALS AND METHODS}

The Plymouth Marine Laboratory (PML) annular flumes are used to generate currents and bed shear stresses similar to those recorded in the field (Pope et al. 2006) and quantify the influence of biota on erodability of marine and estuarine sediments. Previous annular flume studies have shown that results for sediment erodability measured in laboratory-based flumes are similar to those from flumes deployed in situ in the field (Widdows et al. 2000, 2007). The experimental design of the present study involved adding a known number Nereis diversicolor of similar size to cohesive muddy sediment collected from mud-banks in the upper Tamar estuary (Calstock; OS Grid Refer- ence SX437683). This site was chosen because it has a very impoverished infaunal community (Widdows et al. 2007) and is readily accessible using an inflatable boat. The low biodiversity and biomass (primarily very small oligochaetes) was due to the wide tidal salinity fluctuations experienced at this site (0 to $\sim 20 \mathrm{psu}$ on spring tides during the summer period; Uncles \& Stephens 1990) and the recent sediment accretion during the summer months. Sediments in the upper and mid sections of the Tamar have a seasonal cycle of erosion in autumn/winter and accretion during the summer (Bale et al. 1985). Consequently, the mud-banks are made up of relatively homogeneous cohesive sediment with high water content and little evidence of dewatering or further consolidation down to depths of $>10 \mathrm{~cm}$ (Bale et al. 2007). Our experimental approach, involving the collection of sediment from Calstock mud banks in late summer, avoids defaunating the sediment by sieving or freezing, both of which alter the sediment's physical-chemical-biological properties. $N$. diversicolor was collected from a high density population at St. John's Lake (Grid reference SX412539) in the Tamar estuary during August and early September 2007. The mean body length was $5.8 \pm 0.9 \mathrm{~cm}$ (mean \pm $\mathrm{SE}$ ). Sediment and animals were freshly collected for each experiment with different worm densities (100, $300,1000,3000$ individuals $\mathrm{m}^{-2} ; \mathrm{n}=2$ for each density). During each experiment there was a simultaneous flume run with control sediment $\left(0\right.$ ind. $\left.\mathrm{m}^{-2} ; \mathrm{n}=8\right)$.

Flume experiments were carried out in a temperature controlled room $\left(15^{\circ} \mathrm{C}\right)$, with a $10 \mathrm{~h}$ light-14 h dark regime, using seawater of $30 \mathrm{psu}$ (i.e. salinity equivalent to the Nereis diversicolor collection site). Soft cohesive muddy sediment (depth $8 \mathrm{~cm}$ ) was placed in the 2 PML annular flumes, 1 acting as a control without $N$. diversicolor, and the other with the addition of $N$. diversicolor at the required density. Individual worms were distributed evenly around the flume and allowed 30 min to burrow into the sediment. A sheet of 'bubble wrap' the size and shape of the annulus was then carefully placed on the sediment surface and seawater gently pumped onto the sheet, which gradually floated off without disturbing the sediment surface. The flumes were filled with $46 \mathrm{l}$ of water $(27 \mathrm{~cm}$ water depth) and gently aerated to maintain fully oxygenated water prior to erosion experiments. Water flow, ranging from 0.05 to $0.55 \mathrm{~m} \mathrm{~s}^{-1}$, was generated by 4 paddles $(9 \mathrm{~cm} \times 6.5 \mathrm{~cm})$ attached to a rotating cylinder driven by a motor and gear-box with built-in rpm counter. The flume speed was controlled and logged by a portable computer using LabView software (for details see Widdows et al. 1998a, Pope et al. 2006).

The flume was set to maintain a low current speed of $0.05 \mathrm{~m} \mathrm{~s}^{-1}$ overnight $(20 \mathrm{~h})$ and during this time there was measurable sediment resuspension, particularly at 
the 2 highest Nereis diversicolor densities, in comparison with the controls. In the morning, before the start of simultaneous erosion experiments (control and Nereis flumes) $>90 \%$ of the seawater was replaced in the flumes. After a period of $60 \mathrm{~min}$ at $0.05 \mathrm{~m} \mathrm{~s}^{-1}$ the current speeds were increased from 0.05 to $0.55 \mathrm{~m} \mathrm{~s}^{-1}$ in $15 \mathrm{~min}$, $\sim 0.05 \mathrm{~m} \mathrm{~s}^{-1}$ stepwise increments. The resuspension of sediment was determined by an optical backscatter sensor (OBS) recording at $5 \mathrm{~s}$ intervals. The OBS sensor was calibrated against water samples taken for gravimetric analysis during each experimental run. These were filtered onto pre-weighed glass fibre filters (GFC), washed with distilled water, dried at $90^{\circ} \mathrm{C}$ and reweighed together with blank filters. A calibration curve of suspended sediment concentrations $\left(\mathrm{SSC}_{i} \mathrm{mg} \mathrm{l}^{-1}\right)$ vs. OBS output (in V) was produced for each experiment. This allowed the calculation of mass of sediment eroded $\left(\mathrm{ME}_{;} \mathrm{g} \mathrm{m}^{-2}\right)$ and identification of critical erosion thresholds (critical erosion velocity $\left[U_{\text {crit }}\right]$ : $\mathrm{m} \mathrm{s}^{-1}$; and threshold bed shear stress for erosion: $\tau_{\mathrm{e}}$ ).

After examining the density dependent effects of Nereis diversicolor on sediment erosion using the standard incremental increase in current speed/bed shear stress, the effect of a single $N$. diversicolor density (300 ind. $\mathrm{m}^{-2}$ ) on sediment erosion and deposition was studied in the flumes under conditions of continuous sinusoidal tidal cycles with current speeds between 0.05 and $0.35 \mathrm{~m} \mathrm{~s}^{-1}$. The current speeds cycled over a period of $6 \mathrm{~h}$, equivalent to the peak in currents speeds on the flood and ebb tides of a $12.5 \mathrm{~h}$ tidal cycle, and the experiment was terminated after 7 cycles. The sedimentation process associated with decelerating current speeds in the control and experimental flumes was expressed in terms of clearance rate (the volume of water cleared of suspended sediment particles per hour) during each 15 min period. Clearance rate (CR) was calculated from the exponential decline in SSC as:

$$
\mathrm{CR}=V\left(\ln \mathrm{C}_{1}-\ln \mathrm{C}_{2}\right) / t
$$

where $V$ is the volume of the flume (46 l), $t$ is the time interval in $\mathrm{h}$, and $\mathrm{C}_{1}$ and $\mathrm{C}_{2}$ are the SSC at the beginning and end of each time increment (15 min).

A Sontek micro-Acoustic Doppler Velocimeter (ADV) was used to measure vertical profiles in current speed and turbulent kinetic energy (TKE) at $0.5 \mathrm{~cm}$ above the bed and then at $1 \mathrm{~cm}$ intervals from 1 to $9 \mathrm{~cm}$ in each of the Nereis density experiments (as described by Pope et al. 2006). Bed shear stress in the flume studies was calculated from TKE measurements within the compressed boundary layer (i.e. at $z=0.5 \mathrm{~cm}$ ). Current speeds in the flume are expressed as depth-averaged current speeds, but there was a relatively uniform speed between $1 \mathrm{~cm}$ and $9 \mathrm{~cm}$ above the bed. The measured relationship between mean current speed (U) and bed shear stress $\left(\tau_{0}\right)$ in this study (Fig. 1) was

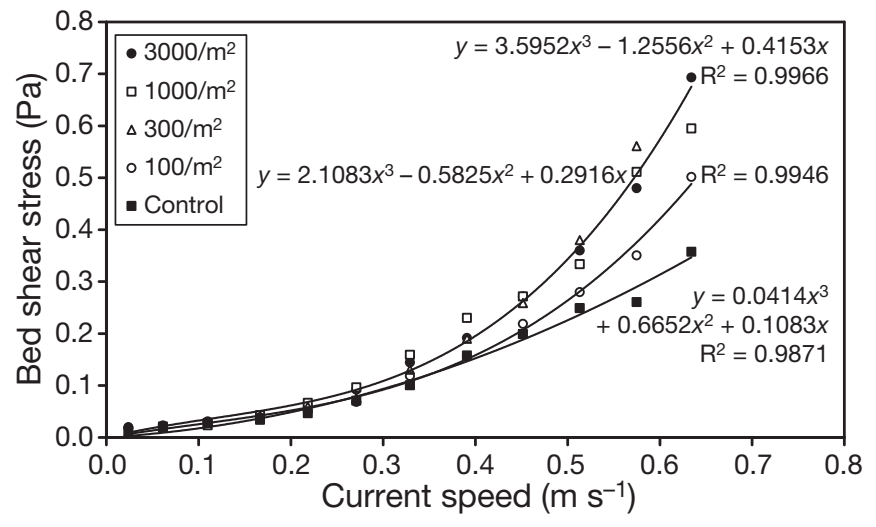

Fig. 1. Relationship between bed shear stress $(\mathrm{Pa})$ and depth-averaged current speed $\left(\mathrm{m} \mathrm{s}^{-1}\right)$ for different densities of Nereis diversicolor ( 0 to 3000 ind. $\mathrm{m}^{-2}$ ). Bed shear stress is derived from turbulent kinetic energy measurements at $0.5 \mathrm{~cm}$ above the bed. Three distinct relationships are identified and described by polynomial equations: (1) bare sediment (0 ind. $\left.\mathrm{m}^{-2}\right) ;(2) 100$ ind. $\mathrm{m}^{-2}$; and (3) 300,1000, 3000 ind. $\mathrm{m}^{-2}$

similar to that recorded for smooth cohesive mud in previous laboratory annular flume studies as well as the field (Pope et al. 2006).

On each sampling occasion at Calstock, sediment samples $(n=3)$ were collected and analysed for physical and biochemical sediment properties (Table 1). Grain size was measured using a laser diffraction particle size analyser (Beckman Coulter LS 230). Measurements also included bulk density (mass of wet sediment/volume of wet sediment), water content (\% water) and a measure of particulate organic matter (POM; by loss on ignition at $450^{\circ} \mathrm{C}$ ). Biological sediment properties, such as microphytobenthos biomass and extracellular polymeric substances (EPS), were estimated in terms of chlorophyll a ( $\mathrm{chl} \mathrm{a}$ ) and colloidal carbohydrate content. These sediment samples were collected by means of cut-off plastic syringes of $12.5 \mathrm{~mm}$ diameter (3 replicate cores). Chl a was analysed by HPLC following acetone extraction (Lucas et al. 2000), and EPS by the phenol-sulphuric acid method (Underwood et al. 1995).

Table 1. Sediment properties of the Calstock sediment collected from intertidal mud banks

\begin{tabular}{|c|c|}
\hline Sediment property & Mean $\pm \operatorname{SE}(n=6)$ \\
\hline Grain size $(\%<63 \mu \mathrm{m})$ & $84.8 \pm 3.10$ \\
\hline Bulk density (g wet wt $\mathrm{cm}^{-3}$ ) & $1.20 \pm 0.00$ \\
\hline$\%$ Water content & $70.9 \pm 0.49$ \\
\hline$\%$ Loss on ignition & $11.04 \pm 0.12$ \\
\hline Chl a ( $\mu g^{-1}$ wet wt) & $3.32 \pm 0.31$ \\
\hline Carbohydrates ( $\mu \mathrm{g} \mathrm{g}^{-1}$ wet wt) & $50.88 \pm 2.75$ \\
\hline
\end{tabular}




\section{RESULTS}

All Nereis diversicolor worms readily burrowed into the muddy sediment within 30 min and had established burrows prior to each erosion experiment. The bed surface was noticeably rougher ( $\mathrm{mm}$ scale) than the control sediment, with visible tracks and mucus trails. At the highest $N$. diversicolor density of 3000 ind. $\mathrm{m}^{-2}$ the water in the flume was significantly turbid $\left(362 \pm 30 \mathrm{mg} \mathrm{l}^{-1}\right)$ after $20 \mathrm{~h}$ at $0.05 \mathrm{~m} \mathrm{~s}^{-1}$, compared with the control flume $\left(12.6 \pm 0.06 \mathrm{mg} \mathrm{l}^{-1}\right)$. The mean rate of active sediment resuspension by $N$. diversicolor at the highest densities (3000 and 1000 ind. $\mathrm{m}^{-2}$ ) was quantified during the hour immediately after replacing the seawater in the flume and before the erosion experiment. There was a steady increase in SSC at the rate of $15.2 \mathrm{mg} \mathrm{l}^{-1} \mathrm{~h}^{-1} \pm 2.05 \mathrm{SE}$, or $4.11 \mathrm{~g} \mathrm{~m}^{-2} \mathrm{~h}^{-1} \pm 0.55$ at a current speed of $0.05 \mathrm{~m} \mathrm{~s}^{-1}$.

During the stepwise erosion experiments the depthaveraged $U$ and $\tau_{0}$ were determined using an ADV. The relationships between $U$ and $\tau_{0}$ for different Nereis diversicolor densities are presented in Fig. 1. Above current speeds of $0.35 \mathrm{~m} \mathrm{~s}^{-1}$ there was a marked influence of $N$. diversicolor on $\tau_{0}$ with increasing $U$. At densities $\geq 300$ ind. $\mathrm{m}^{-2}$ and at current speeds of 0.4 and $0.5 \mathrm{~m} \mathrm{~s}^{-1}$ there was $\sim 30$ and $50 \%$ increase in $\tau_{0}$, respectively, compared to the control sediment. At the lowest density (100 ind. $\mathrm{m}^{-2}$ ) there was a $17 \%$ increase in $\tau_{0}$ at $0.5 \mathrm{~m} \mathrm{~s}^{-1}$ relative to the controls. At these flows the surface sediment would have been eroded, therefore the increased bed shear stress was probably due primarily to the water flow over the burrow openings at the sediment surface.

Nereis diversicolor had a marked impact on sediment erodability at flow rates above $0.15 \mathrm{~m} \mathrm{~s}^{-1}$ and at densities of $\geq 300$ ind. $\mathrm{m}^{-2}$ (Fig. 2A). Extrapolation of the erosion curves (Fig. 2B) to the onset of sediment resuspension (i.e. Type 1a erosion [Amos et al. 1992] representing the resuspension of flocs and recently deposited material not incorporated into the bed) provided $U_{\text {crit }}$ values between 0.11 and $0.12 \mathrm{~m} \mathrm{~s}^{-1}$. The ability to detect the early onset of sediment resuspension at these low current speeds is due to the sensitivity of the OBS sensor (detection limit of $1.5 \mathrm{mg} \mathrm{l}^{-1}$ ), but this $U_{\text {crit }}$ (for Type 1a erosion) is probably not of great environmental significance. The cohesive mud in the controls without $N$. diversicolor showed little evidence of major bed erosion (Type $1 \mathrm{~b}$ ) until currents were $>0.45 \mathrm{~m} \mathrm{~s}^{-1}$. In contrast, densities of 1000 and 3000 individuals $\mathrm{m}^{-2}$ had destabilised the bed and enhanced sediment erosion to values equivalent to the controls (i.e. $18 \mathrm{~g}$ sediment $\mathrm{m}^{-2}$ at $0.4 \mathrm{~m} \mathrm{~s}^{-1}$ ), but at current speeds as low as $0.15 \mathrm{~m} \mathrm{~s}^{-1}$. At the highest worm density, sediment mass eroded relative to the controls had increased by $20 \times, 25 \times$, and $37 \times$ at $0.2,0.3$ and $0.4 \mathrm{~m} \mathrm{~s}^{-1}$, respectively. Fig. 3 illustrates the linear relationship
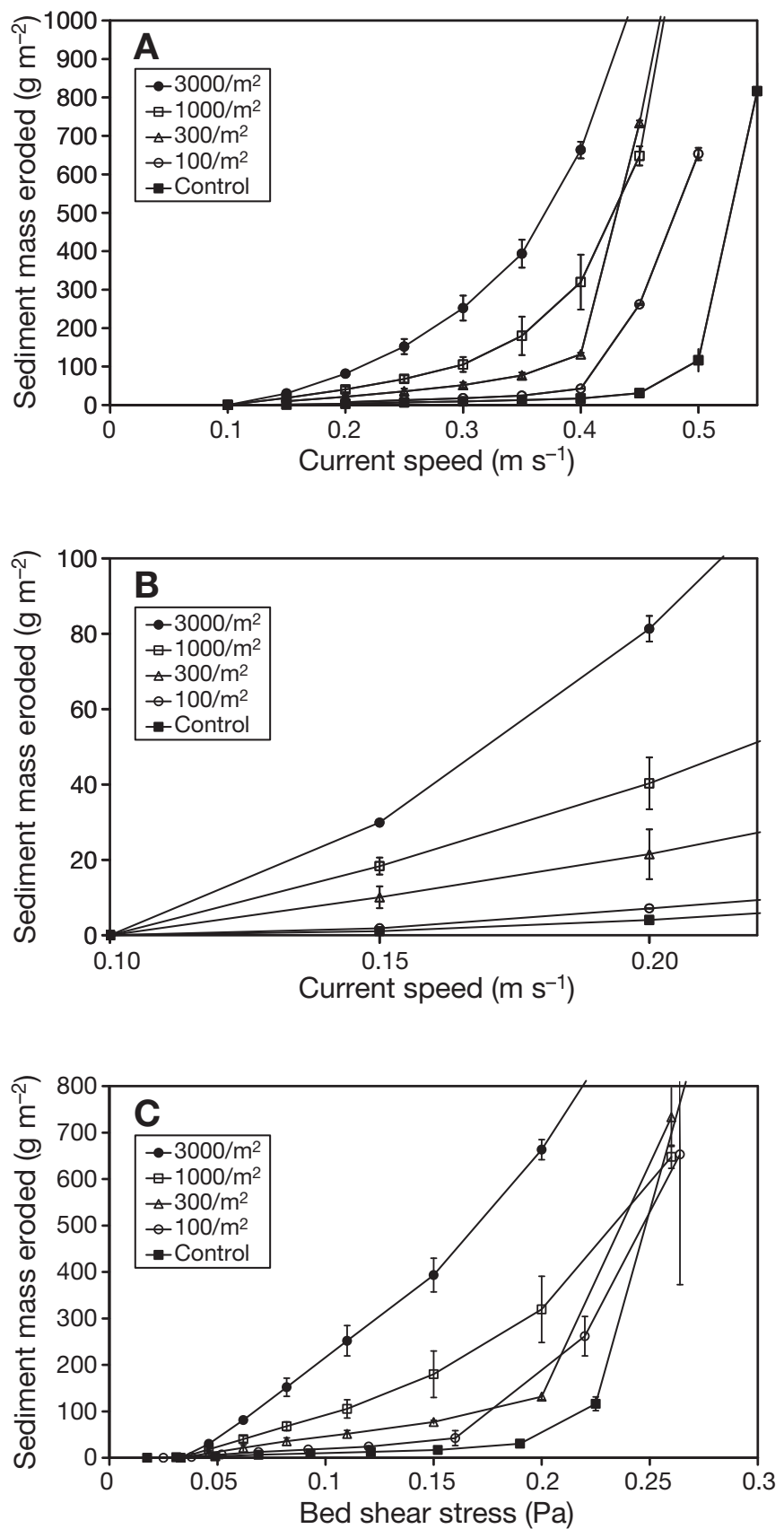

Fig. 2. (A) Relationship between sediment mass eroded $\left(\mathrm{g} \mathrm{m}^{-2}\right)$ and depth-averaged current speed $\left(\mathrm{m} \mathrm{s}^{-1}\right)$ for different densities of Nereis diversicolor (0/bare mud, 100, 300, 1000 and 3000 ind. $\mathrm{m}^{-2}$ ) in response to a step-wise increase in current speed. Initial onset of erosion (enlarged in B) occurred at $0.11 \mathrm{~m} \mathrm{~s}^{-1}$ (Type 1a erosion) whereas significant bed erosion (Type $1 \mathrm{~b}$ ) was delayed until currents were $>0.4 \mathrm{~m} \mathrm{~s}^{-1}$ at the 3 lowest densities $\left(0,100\right.$ and 300 ind. $\left.\mathrm{m}^{-2}\right)$. (C) Relationship between sediment mass eroded $\left(\mathrm{g} \mathrm{m}^{-2}\right)$ and bed shear stress (Pa) for different densities (ind. $\mathrm{m}^{-2}$ ). Resuspension of loose floc material was initiated at 0.02 to $0.036 \mathrm{~Pa}$ (Type 1a) and this was followed by bed erosion (Type $1 \mathrm{~b}$ ) at the 2 highest densities. Significant bed erosion only occurred at $>0.15 \mathrm{~Pa}$ at the 3 lowest densities $\left(0,100\right.$ and 300 ind. $\left.\mathrm{m}^{-2}\right)$ 


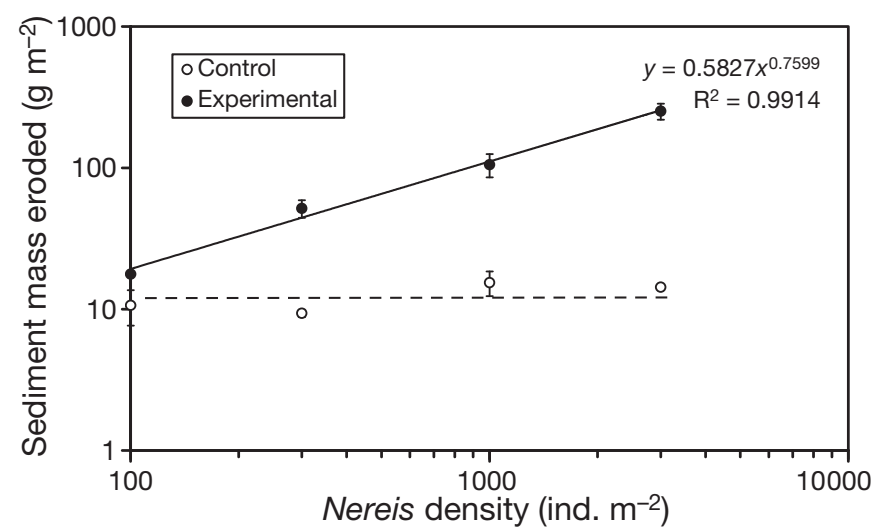

Fig. 3. Linear relationship between log sediment mass eroded $\left(\mathrm{g} \mathrm{m}^{-2}\right)$ and $\log$ density of Nereis diversicolor (ind. $\left.\mathrm{m}^{-2}, \mathbf{0}\right)$, together with respective controls $\left(0\right.$ ind. $\left.\mathrm{m}^{-2}, \mathrm{O}\right)$, at a current speed of $0.3 \mathrm{~m} \mathrm{~s}^{-1}$

between $\log$ sediment mass eroded and $\log N$. diversicolor density at a current speed of $0.3 \mathrm{~m} \mathrm{~s}^{-1}$ together with the respective controls.

The relationships between sediment mass eroded and bed shear stress at the different Nereis diversicolor densities are illustrated in Fig. 2C. It shows that sediment resuspension was initiated (Type 1a erosion) at a similar bed shear stress, regardless of $N$. diversicolor density, and continued over a wide range of current speeds with associated $\tau_{0}$ values from 0.03 to $>0.15 \mathrm{~Pa}$. Erosion thresholds representing the onset of sediment resuspension (Type 1a erosion), whether expressed in terms of $U_{\text {crit }}$ or critical bed shear stress for erosion $\left(\tau_{\mathrm{e}}\right)$, were very similar for all conditions with a narrow range for $U_{\text {crit }}\left(0.11\right.$ to $\left.0.12 \mathrm{~m} \mathrm{~s}^{-1}\right)$ and $\tau_{\mathrm{e}}(0.02$ to $0.036 \mathrm{~Pa}$ ). Although sediment resuspension was detectable at flows $<0.4 \mathrm{~m} \mathrm{~s}^{-1}$ or $0.15 \mathrm{~Pa}$ in the controls and lowest worm density ( 0 and 100 ind. $\mathrm{m}^{-2}$ ) this was minimal compared with the higher densities. At current speeds of $0.4 \mathrm{~m} \mathrm{~s}^{-1}$ approximately $40 \%$ of the sediment mass erosion at the high worm density (3000 N. diversicolor $\mathrm{m}^{-2}$ ) was due to the worms' influence on the higher $\tau_{0}$ (i.e. $0.20 \mathrm{~Pa}$ compared to $0.15 \mathrm{~Pa}$ for the control). The remaining $60 \%$ was due to the destabilisation of the surface sediment by the worms and the higher erosion rate. At the lowest $N$. diversicolor densities $\left(0,100\right.$ and 300 ind. $\left.\mathrm{m}^{-2}\right)$ there was a second major inflexion in the erosion curves at flows $>0.4 \mathrm{~m} \mathrm{~s}^{-1}$ or 0.15 to $0.2 \mathrm{~Pa}$, which reflects the major erosion of bed sediments (Type $1 \mathrm{~b}$ erosion).

The influence of worm density on bed sediment erosion can be more clearly demonstrated at lower flows when log sediment mass eroded is plotted against log current speed (as described by Widdows et al. 1998a). Fig. 4 provides a series of distinct parallel linear relationships, even separating the lowest worm density from the control. The displacement of these regression

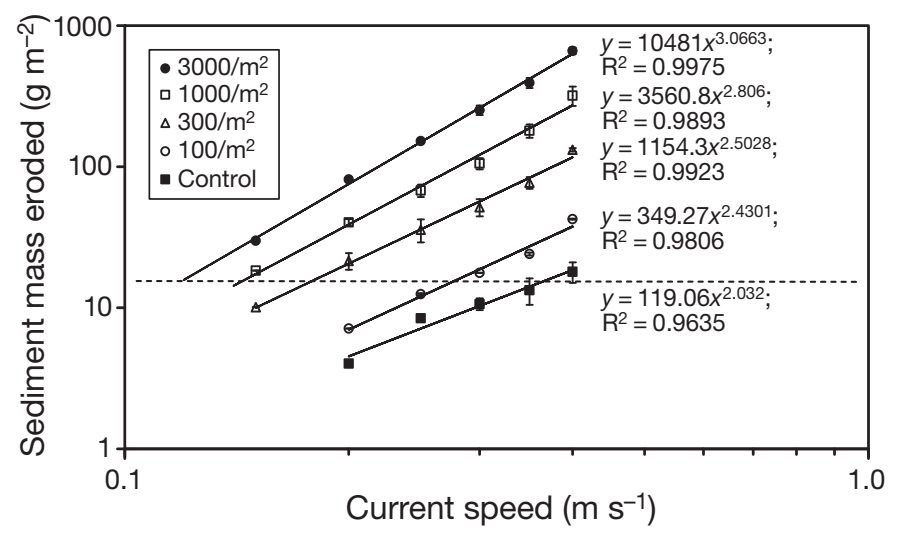

Fig. 4. Log sediment mass eroded $\left(\mathrm{g} \mathrm{m}^{-2}\right)$ vs. $\log$ current speed $\left(\mathrm{m} \mathrm{s}^{-1}\right)$ illustrating linear relationships and exponential equations for deriving critical erosion thresholds, defined in terms of critical current speed $\left(U_{\text {crit }}\right)$ inducing sediment resuspension above a threshold of $15 \mathrm{~g} \mathrm{~m}^{-2}$. $U_{\text {crit }}$ declines from 0.36 to $0.27,0.18,0.14$ and $0.12 \mathrm{~m} \mathrm{~s}^{-1}$ with increasing Nereis diversicolor density from 0 to 100, 300, 1000 and 3000 ind. $\mathrm{m}^{-2}$

lines reflects the combined effect of several processes including resuspension of flocs (control and experimental flumes), the density-dependent active resuspension, increased bed roughness and $\tau_{0}$ (at densities $>300$ ind. $\mathrm{m}^{-2}$ ), as well as the erosion of surficial sediments loosened by Nereis diversicolor. Inevitably there is no extrapolation to zero mass eroded for a log-log plot, therefore $U_{\text {crit }}$ is defined as the velocity required to erode $15 \mathrm{~g}$ sediment $\mathrm{m}^{-2}$ (an arbitrary but relatively low threshold equivalent to $50 \mathrm{mg} \mathrm{l}^{-1}$ and one that is able to separate erosion curves and produce environmentally realistic $U_{\text {crit }}$ values; Roast et al. 2004). The $U_{\text {crit }}$ values derived from this log-log plot declined from 0.36 to $0.27,0.18,0.14$ and $0.12 \mathrm{~m} \mathrm{~s}^{-1}$ with increasing $N$. diversicolor density from 0 to $100,300,1000$ and 3000 ind. $\mathrm{m}^{-2}$.

Nereis diversicolor maintained under continuous sinusoidal tidal cycles of current speeds between 0.05 and $0.35 \mathrm{~m} \mathrm{~s}^{-1}$ showed a consistent response after the initial cycle when worms were establishing their burrows and feeding behaviour (Fig. 5). Under a cyclic current regime mimicking the environment (e.g. 0.06 to $0.36 \mathrm{~m} \mathrm{~s}^{-1}$ at spring tides on the lower shore at Cargreen, mid Tamar) there was regular sediment resuspension and deposition in the control flume with a consistent maximum and minimum SSC. In the experimental flume with $N$. diversicolor the peak SSC during the first cycle was similar to the control but thereafter the maximum values were very consistent for cycles 2 , 3 and 4 . This indicated that a steady state had been reached within $12 \mathrm{~h}$ and that the ongoing activity or mucus secretion by $N$. diversicolor did not significantly modify sediment erodability further over time. Sediment in the control flume cycled between 22 and 


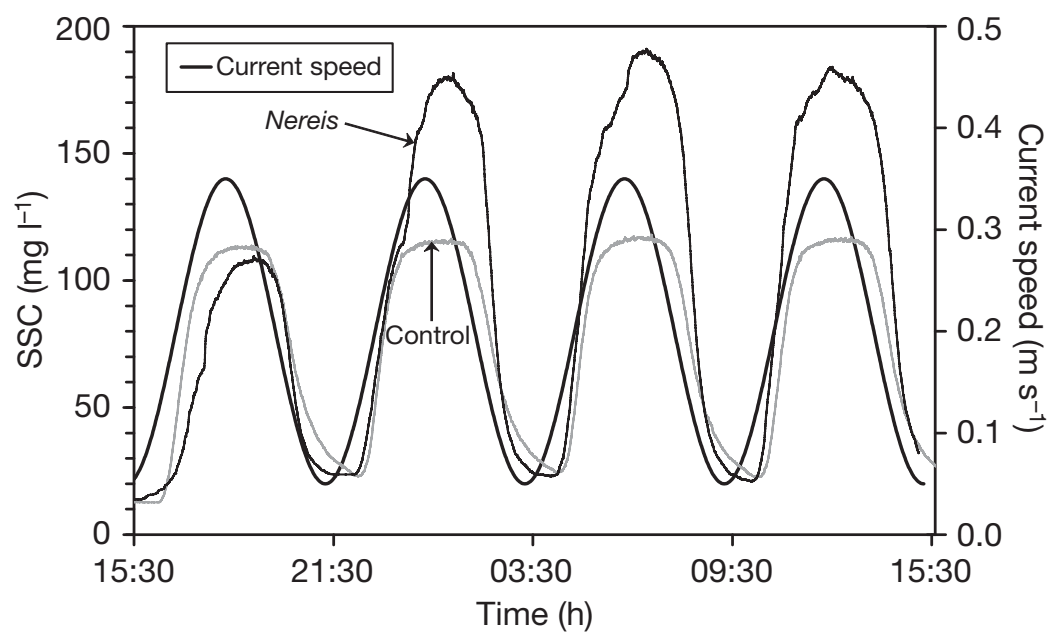

Fig. 5. Effect of continuous sinusoidal tidal-current cycles on suspended sediment concentration (SSC) in 2 flumes run in parallel (control: without worms, light grey; experimental: with 300 Nereis diversicolor $\mathrm{m}^{-2}$, black). Current speeds ranged from 0.05 to $0.35 \mathrm{~m} \mathrm{~s}^{-1}$ with a cycle duration of $6 \mathrm{~h}$. Note consistent response after initial cycle

$115 \mathrm{mg} \mathrm{l}^{-1}$ (6 and $32 \mathrm{~g} \mathrm{~m}^{-2}$ ) and between 22 and $190 \mathrm{mg} \mathrm{l}^{-1}$ (6 and $53 \mathrm{~g} \mathrm{~m}^{-2}$ ) in the experimental flume with $N$. diversicolor at a density of 300 individuals $\mathrm{m}^{-2}$. These maximum values were similar to the sediment mass eroded during the step-wise erosion experiments at current speeds of $0.35 \mathrm{~m} \mathrm{~s}^{-1}$ (controls: $13 \mathrm{~g} \mathrm{~m}^{-2}$; 300 worms $\mathrm{m}^{-2}: 77 \mathrm{~g} \mathrm{~m}^{-2}$ ) and were consistent with an intermediate value between worm densities of 100 and 1000 ind. $\mathrm{m}^{-2}$ (i.e. 24 and $180 \mathrm{~g} \mathrm{~m}^{-2}$; Fig. 2A).

The cyclic nature of the currents resulted in cyclic processes of resuspension and deposition, with evidence of a marked delay in the onset of erosion and deposition until the critical erosion and deposition thresholds had been reached (Fig. 5). Following the conversion of SSC to mass eroded and deposited for each 15 min interval, the processes of sediment erosion and deposition, and the critical thresholds become more apparent (Fig. 6). The onset of erosion $\left(U_{\text {crit }}\right)$ occurred on the accelerating part of the cycle at a current speed of $0.11 \mathrm{~m} \mathrm{~s}^{-1}\left(\tau_{\mathrm{e}}=0.02 \mathrm{~Pa}\right)$ with the experimental flume containing Nereis diversicolor beginning to erode slightly in advance of the control flume. The erosion threshold for the cyclic current speeds was therefore consistent with the Type 1a erosion recorded in the step-wise erosion experiments (Fig. 2A). During the period of rapidly accelerating flows between 0.13 and $0.20 \mathrm{~m} \mathrm{~s}^{-1}$ the sediment erosion rate in the experimental flume was $\sim 2$-fold higher than the control. A maximum rate of erosion occurred at $0.25 \mathrm{~m} \mathrm{~s}^{-1}\left(\tau_{0}=0.07 \mathrm{~Pa}\right)$, with the erosion rate then declining as current speeds gradually peaked at $0.35 \mathrm{~m} \mathrm{~s}^{-1}$. During the early phase of the decelerating part of the cycle there was a steady decline in the erosion rate until the beginning of sediment deposition phase. The deposition threshold was at $0.26 \mathrm{~m} \mathrm{~s}^{-1}\left(\tau_{\mathrm{d}}=\right.$ $0.07 \mathrm{~Pa}$ ) and the maximum deposition rate occurred at $0.11 \mathrm{~m} \mathrm{~s}^{-1}\left(\tau_{0}=\right.$ $0.02 \mathrm{~Pa})$, declining rapidly as the current speeds reach the minimum values. The deposition thresholds were similar in the experimental and control flumes, but the deposition rate in the flume with $N$. diversicolor was 2 -fold higher than in the control. During decelerating flows between 0.26 and $0.19 \mathrm{~m} \mathrm{~s}^{-1}$ there was little difference between the experimental and control when expressed in terms of clearance rates $\left(\mathrm{l} \mathrm{h}^{-1}\right)$. However, between 0.15 and $0.08 \mathrm{~m} \mathrm{~s}^{-1}$ there was a consistently higher clearance rate $(\times 1.9)$ in the experimental compared to the control flume (Table 2). This higher sedimentation rate was not simply the result of higher SSC in the experimental flume containing $N$. diversicolor because at flows between 0.08 and $0.06 \mathrm{~m} \mathrm{~s}^{-1}$, the SSC in both experimental and control flumes had declined to similar values $\left(\sim 50 \mathrm{mg} \mathrm{l}^{-1}\right)$. At these comparable flows and SSC the mean clearance rate for the flume with $N$. diversicolor

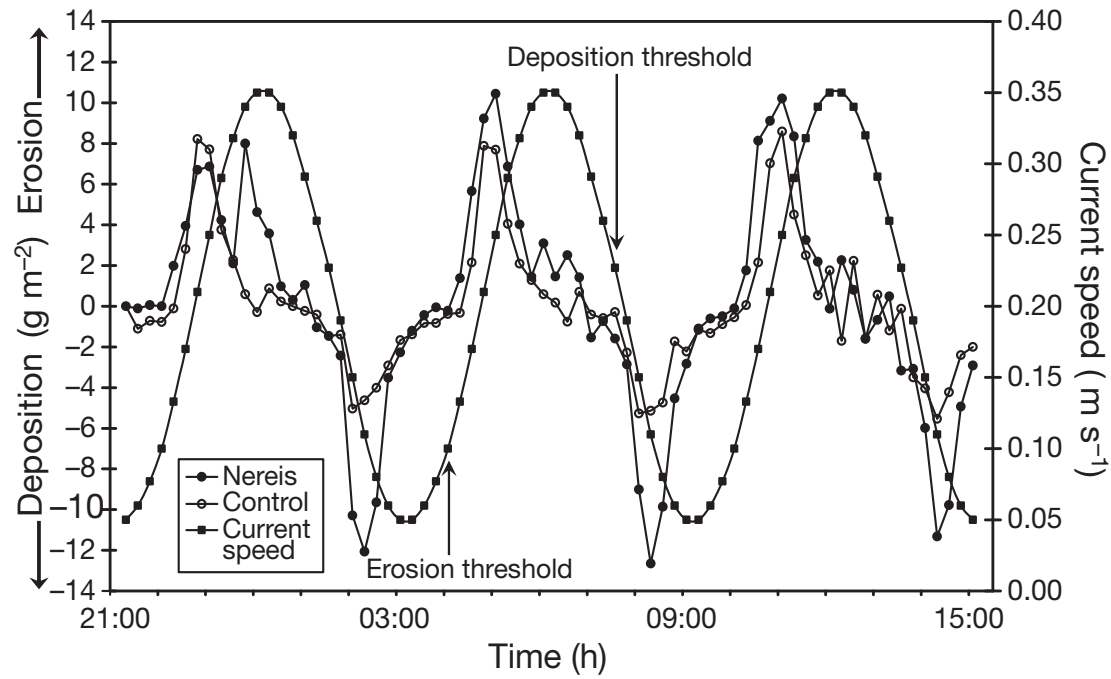

Fig. 6. Erosion and deposition rates ( $\mathrm{g} \mathrm{m}^{-2}$ calculated for each $15 \mathrm{~min}$ interval) for control $(\mathrm{O})$ and experimental densities of Nereis diversicolor $\left(300\right.$ ind. $\left.\mathrm{m}^{-2}, \mathbf{0}\right)$ illustrating erosion and deposition thresholds and peaks in response to tidal-current cycles (current velocity $\left.\mathrm{m} \mathrm{s}^{-1}, \mathbf{\square}\right)$ over 3 cycles $(2 \mathrm{nd}-4 \mathrm{th}$ ) 
was still $\sim 2$-fold higher $\left(60 \pm 3.31 \mathrm{~h}^{-1}\right)$ than the control $\left(32 \pm 4.21 \mathrm{~h}^{-1}\right.$; ANOVA; $\left.\mathrm{p}<0.01\right)$. The difference between the experimental and control clearance rates may reflect the clearance rate by $N$. diversicolor, which corresponds to an individual clearance rate of $1.53 \pm 0.41 \mathrm{ml} \mathrm{min}^{-1}$. After attaining the minimum current speed of $0.05 \mathrm{~m} \mathrm{~s}^{-1}$, and during the first hour of increasing current speeds from 0.05 to $0.11 \mathrm{~m} \mathrm{~s}^{-1}$, there was little change in SSC (i.e. no further deposition and no erosion).

\section{DISCUSSION}

The present flume study has demonstrated the important role of Nereis diversicolor in destabilising the sediment and increasing its erodability in response to relatively low to moderate tidal currents (i.e. 0.1 to $0.30 \mathrm{~m} \mathrm{~s}^{-1}$ ). This is similar to other bio-destabilisers or bioturbators of sediment (e.g. Neomysis integer, Roast et al. 2004; Corophium volutator, de Deckere et al. 2000; Macoma balthica, Widdows et al. 1998b; Cerastoderma edule, Ciutat et al. 2006; Hydrobia ulvae, Andersen et al. 2002, Orvain et al. 2006). The present results, derived from laboratory experiments, are comparable with field studies investigating sediment erodability with distance down the Tamar (Bale et al. 2007). Our results are also consistent with previous field studies using PML's annular flumes to measure spatial and temporal variation in sediment erodability in relation to natural changes in benthic community composition (Widdows et al. 2006). These showed a statistically significant positive correlation between $N$. diversicolor density and mass of sediment eroded, as well as a negative correlation between density and $U_{\text {crit, }}$ where $U_{\text {crit }}$ reflected Type $1 \mathrm{~b}$ erosion of bed sediment rather than the initial resuspension of flocs or Type 1a erosion.

Field measurements of near-bed current speeds (at $z=0.05 \mathrm{~m}$ ) recorded over intertidal mudflats in the middle to upper Tamar and Tavy estuaries (Widdows et al. 2008) show current speeds comparable to the range of $U_{\text {crit }}$ values (i.e. 0.36 to $0.12 \mathrm{~m} \mathrm{~s}^{-1}$ ) recorded in the present flume studies. At Cargreen, near the Clifton site where Nereis diversicolor are most abundant, peak flows on the flood tide $\left(0.38 \mathrm{~m} \mathrm{~s}^{-1}\right)$ were associated with maximum SSC of $800 \mathrm{mg} \mathrm{l}^{-1}$ in $0.6 \mathrm{~m}$ depth of water, or $480 \mathrm{~g} \mathrm{~m}^{-3}$ water above $1 \mathrm{~m}^{2}$ of sediment. At the time when these SSC were measured (February 2000) the $N$. diversicolor density was only 406 individuals $\mathrm{m}^{-2}$ (i.e. less than recorded maximum densities). The mass of sediment eroded at $0.35 \mathrm{~m} \mathrm{~s}^{-1}$ and densities of 300 and
1000 ind. $\mathrm{m}^{-2}$ (Fig. 2A) were 77 and $180 \mathrm{~g} \mathrm{~m}^{-2}$ respectively, therefore at a density of $406 \mathrm{~N}$. diversicolor $\mathrm{m}^{-2}$ it is estimated that $\sim 95 \mathrm{~g} \mathrm{~m}^{-2}$ might be eroded. This represents $20 \%$ of the sediment mass in the water column $\left(480 \mathrm{~g} \mathrm{~m}^{-3}\right)$, assuming that most of the SSC was generated by resuspension during peak flood flows over the Cargreen mudflat, rather than simply advection from the main channel. Based on these estimates N. diversicolor could therefore make a significant contribution to the SSC in the upper part of the estuary. At the highest density of 3000 ind. $\mathrm{m}^{-2}$ (Spooner \& Moore 1940, Warwick \& Gee 1984, Warwick et al. 1991) they could contribute up to $50 \%$ of the SSC on the flood tide due to the higher erosion rates.

Although there was no evidence of suspension feeding by Nereis diversicolor held under conditions of low SSC and low currents prior to the step-wise flume erosion experiments, there was evidence of enhanced sediment deposition (i.e. 2-fold increase in clearance rates) in the experimental flumes during the 3 consecutive sinusoidal tidal cycles of erosion and deposition (Fig. 5, Table 2). The initial stage of sedimentation was probably mainly associated with the more rapid settlement of suspended aggregates (including faecal pellets), similar to that reported for Hydrobia ulvae by Andersen \& Pejrup (2002). The difference between the clearance rates for the experimental and control flumes at decelerating flows between 0.08 and $0.06 \mathrm{~m} \mathrm{~s}^{-1}$, when the SSC were similar and therefore not directly influencing deposition rates, 
provides an estimate of the possible clearance rates of individual worms. Presumably at this later stage in the decelerating phase all of the larger and heavier aggregates would have settled on the bed. However, the mean value of $1.53 \pm 0.41 \mathrm{ml} \mathrm{min}^{-1}$ ind. $^{-1}$ was low compared with previous estimates of clearance rates in relatively clear Dan-

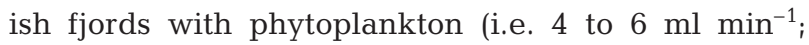
Nielsen et al. 1995, Riisgård et al. 1996). In addition, under the simulated tidal-current cycles (at density of 300 ind $\mathrm{m}^{-2}$ ) there was no evidence of active resuspension by $N$. diversicolor or that the ventilatory currents from the worm burrows hindered the settlement of suspended sediments at the lower current speeds of $0.05 \mathrm{~m} \mathrm{~s}^{-1}$.

Suspension feeding by Nereis diversicolor has been widely reported in Danish fjord systems (Riisgård et al. 1996, 2007, Vedel 1998). In the present flume study, however, there was no evidence of suspension feeding activity when $N$. diversicolor was held in soft cohesive muddy sediment at low current speeds $\left(0.05 \mathrm{~m} \mathrm{~s}^{-1}\right)$, with low suspended particulate matter (SPM of $12 \mathrm{mg} \mathrm{l}^{-1}$ ) and without the addition of phytoplankton cells. This is consistent with earlier studies by Vedel \& Riisgård (1993) and Nielsen et al. (1995) that showed $N$. diversicolor ceases suspension feeding in relatively clear water with phytoplankton below a threshold concentration of 1500 to 3000 cells ml ${ }^{-1}$. Suspension feeding was considered no longer profitable. In contrast, the present study showed $N$. diversicolor worms at the highest densities caused significant rates of sediment resuspension, whilst held at low current speeds (i.e. at $0.05 \mathrm{~m} \mathrm{~s}^{-1}$ and below that required to resuspend and entrain sediment particles). This active process of sediment resuspension has also been recorded for the mysid Neomysis integer (Roast et al. 2004) and the amphipod Corophium volutator (de Deckere et al. 2000), 2 other species living at high densities in the upper estuary. The mechanism of active resuspension was readily observed in hyperbenthic mysids (i.e. they collect a ball of sediment from the bed and then rejoin the swarm swimming in the water column, where they feed on the sediment particles and associated meioand micro-organisms). However, the process of active resuspension was not readily observed in $N$. diversicolor. The mechanism was probably associated with the ejection of ingested and/or disturbed sediment from within the burrow system, as well as occasional foraging on the surface sediments.

The use of tidal-current cycles in the flume studies has provided new insight into the erosion and deposition thresholds for fine muddy sediments. The present study has demonstrated a consistent and markedly higher deposition threshold $\left(0.26 \mathrm{~m} \mathrm{~s}^{-1}\right.$ or $\left.0.07 \mathrm{~Pa}\right) \mathrm{com}$ pared to the erosion threshold $\left(0.11 \mathrm{~m} \mathrm{~s}^{-1}\right.$ or $\left.0.02 \mathrm{~Pa}\right)$. This is similar to the field results of Sanford \& Halka
(1993) who showed that deposition of mud over the tidal cycle was initiated soon after the shear stress began to decrease and long before the stress declined below the critical erosion threshold. Although the deposition threshold is in good agreement with published values of 0.06 to $0.1 \mathrm{~Pa}$ for the critical shear stress for deposition of cohesive sediments $\left(\tau_{\mathrm{d}}\right)$ (Whitehouse et al. 2000 ), our data are not consistent with the view that $\tau_{\mathrm{d}}$ is approximately half the value of the threshold bed shear stress for erosion (Whitehouse et al. 2000). If the erosion threshold is defined using a threshold of $15 \mathrm{~g} \mathrm{~m}^{-2}$, as in Fig. 4, then our results for control sediment are consistent with this statement. However, $N$. diversicolor significantly reduces the erosion threshold of the bed sediment to values below the $\tau_{\mathrm{d}}$ at the 3 highest worm densities (Fig. 4). Furthermore, the continuous erosion and deposition of sediment in the cyclic flume experiment and in the field will tend to lower the erosion threshold $\left(\tau_{\mathrm{e}}\right)$ to values below the $\tau_{\mathrm{d}}$ because flocs and recently deposited material will not be incorporated into the bed before it is resuspended again.

The abundant estuarine worm Nereis diversicolor has a significant effect on sediment erodability over a wide range of worm densities representative of mid to upper mudflats of muddy estuaries such as the Tamar. Flume experiments, including those with sinusoidal tidal-current cycles, suggest that $N$. diversicolor could make a significant contribution to the erosion (and transport) of fine intertidal sediments and therefore to the overall turbidity in the upper estuary.

Acknowledgements. This study was funded by the Natural Environment Research Council core research programme at the Plymouth Marine Laboratory.

\section{LITERATURE CITED}

Ait Alla A, Gillet P, Deutsch B, Moukrim A, Bergayou H (2006) Response of Nereis diversicolor (Polychaeta, Nereidae) populations to reduced wastewater discharge in the polluted estuary of Oued Souss, Bay of Agadir, Morocco. Estuar Coast Shelf Sci 70:633-642

Amos CL, Brylinsky M, Sutherland TF, O'Brien D, Lee S, Cramp A (1992) Sea Carousel — a benthic annular flume. Estuar Coast Shelf Sci 34:557-577

- Andersen TJ, Pejrup M (2002) Biological mediation of the settling velocity of bed material eroded from an intertidal mudflat, the Danish Wadden Sea. Estuar Coast Shelf Sci 54:737-745

Andersen TJ, Jensen KT, Lund-Hansen L, Mouritsen KN, Pejrup M (2002) Enhanced erodibility of fine-grained marine sediment by Hydrobia ulvae. J Sea Res 48:51-58

Bale AJ, Morris AW, Howland RJM (1985) Seasonal sediment movement in the Tamar Estuary. Oceanol Acta 8:1-6

> Bale AJ, Stephens JA, Harris CB (2007) Critical erosion profiles in macro-tidal estuary sediments: implications for the stability of intertidal mud and the slope of mud banks. Cont Shelf Res 27:2303-2312 
Ciutat A, Widdows J, Readman JW (2006) Influence of cockle Cerastoderma edule bioturbation and tidal-current cycles on resuspension of sediment and polycyclic aromatic hydrocarbons. Mar Ecol Prog Ser 328:51-64

de Deckere EMGT, van de Koppel J, Heip CHR (2000) The influence of Corophium volutator abundance on resuspension. Hydrobiologia 426:37-42

de Deckere EMGT, Tolhurst TJ, de Brouwer JFC (2001) Destabilization of cohesive intertidal sediments by infauna. Estuar Coast Shelf Sci 53:665-669

Engelsen A, Pihl L (2008) Grazing effects by Nereis diversicolor on development and growth of green algal mats. J Sea Res 59:228-236

Fernandes S, Sobral P, Costa MH (2006) Nereis diversicolor effect on the stability of cohesive intertidal sediments. Aquat Ecol 40:567-579

Gillet P, Mouloud M, Durou C, Deutch B (2008) Response of Nereis diversicolor population (Polychaeta, Nereididae) to the pollution impact-Authie and Seine estuaries (France). Estuar Coast Shelf Sci 76:201-210

Lawton JH, Jones CG (1995) Linking species and ecosystems: Organisms as ecosystem engineers. In: Jones CG, Lawton $\mathrm{JH}$ (eds) Linking species and ecosystems. Chapman \& Hall, New York, p 141-150

Lucas CH, Widdows J, Brinsley MD, Salkeld PN, Herman PMJ (2000) Benthic-pelagic exchange of microalgae at a tidal flat. 1. Pigment analysis. Mar Ecol Prog Ser 196:59-73

Meadows PS, Tait J (1989) Modification of sediment permeability and shear strength by two burrowing invertebrates. Mar Biol 101:75-82

Meadows PS, Tait J, Hussain SA (1990) Effects of estuarine infauna on sediment stability and particle sedimentation. Hydrobiologia 190:263-266

Nielsen AM, Eriksen NT, Lønnsmann Iversen JJ, Riisgård HU (1995) Feeding, growth and respiration in the polychaetes Nereis diversicolor (facultative filter-feeder) and $N$. virens (omnivorous) - a comparative study. Mar Ecol Prog Ser 125:149-153

> Orvain F, Sauriau PG, Bacher C, Prineau M (2006) The influence of sediment cohesiveness on bioturbation effects due to Hydrobia ulvae on the initial erosion of intertidal sediments: a study combining flume and model approaches. J Sea Res 55:54-73

Paramor OAL, Hughes RG (2004) The effects of bioturbation and herbivory by the polychaete Nereis diversicolor on loss of saltmarsh in south-east England. J Appl Ecol 41:449-463

> Pope ND, Widdows J, Brinsley MD (2006) Estimation of bed shear stress using the turbulent kinetic energy approach - a comparison of annular flume and field data. Cont Shelf Res 26:959-970

Rhoads DC, Young DK (1970) The influence of deposit feeding organisms on sediment stability and community trophic structure. J Mar Res 28:150-178

Riisgård HU, Poulsen L, Larsen PS (1996) Phytoplankton reduction in near-bottom water caused by filter-feeding Nereis diversicolor - implication for worm growth and population grazing impact. Mar Ecol Prog Ser 141:47-54

Riisgård HU, Lassen J, Kortegaard M, Møller LF, Friedrichs M, Jensen MH, Larsen PS (2007) Interplay between filterfeeding zoobenthos and hydrodynamics in the shallow Odense Fjord (Denmark) - earlier and recent studies, perspectives and modelling. Estuar Coast Shelf Sci 75: 281-295

Roast SD, Widdows J, Pope ND, Jones MB (2004) Sedimentbiota interactions: mysid feeding activity enhances water turbidity and sediment erodability. Mar Ecol Prog Ser 281:145-154

> Sanford LP, Halka JP (1993) Assessing the paradigm of mutually exclusive erosion and deposition of mud, with examples from upper Chesapeake Bay. Mar Geol 114:37-57

Spooner GM, Moore HB (1940) The ecology of the Tamar Estuary. VI. An account of the macrofauna of the intertidal muds. J Mar Biol Assoc UK 24:283-330

> Uncles RJ, Stephens JA (1990) Computed and observed currents, elevations and salinity in a branching estuary. Estuaries 13:133-144

Underwood GJC, Paterson DM, Parkes RJ (1995) The measurement of microbial carbohydrate exopolymers from intertidal sediments. Limnol Oceanogr 40:1243-1253

Vedel A (1998) Phytoplankton depletion in the benthic boundary layer caused by suspension-feeding Nereis diversicolor (Polychaeta): grazing impact and effect of temperature. Mar Ecol Prog Ser 163:125-132

> Vedel A, Riisgård HU (1993) Filter-feeding in the polychaete Nereis diversicolor: growth and bioenergetics. Mar Ecol Prog Ser 100:145-152

Warwick RM, Gee JM (1984) Community structure of estuarine meiobenthos. Mar Ecol Prog Ser 18:97-111

Warwick RM, Goss-Custard JD, Kirby R, George CL, Pope ND, Rowden AA (1991) Static and dynamic environmental factors determining the community structure of estuarine macrobenthos in SW Britain: Why is the Severn estuary different? J Appl Ecol 28:329-345

Whitehouse R, Soulsby R, Roberts W, Mitchener H (2000) Dynamics of estuarine muds. Thomas Telford, London

Widdows J, Brinsley MD (2002) Impact of biotic and abiotic processes on sediment dynamics and the consequences to the structure and functioning of the intertidal zone. J Sea Res 48:143-156

- Widdows J, Brinsley MD, Bowley N, Barrett C (1998a) A benthic annular flume for in situ measurement of suspension feeding/biodeposition rates and erosion potential of intertidal cohesive sediments. Estuar Coast Shelf Sci 46:27-38

> Widdows J, Brinsley MD, Salkeld PN, Elliott M (1998b) Use of annular flumes to determine the influence of current velocity and biota on material flux at the sediment-water interface. Estuaries 21:552-559

> Widdows J, Brinsley MD, Salkeld PN, Lucas CH (2000) Influence of biota on spatial and temporal variation in sediment erodability and material flux on a tidal flat (Westerschelde, Netherlands). Mar Ecol Prog Ser 194:23-37

Widdows J, Brinsley MD, Pope ND, Staff FJ, Bolam SG, Somerfield PJ (2006) Changes in biota and sediment erodability following the placement of fine dredged material on upper intertidal shores of estuaries. Mar Ecol Prog Ser 319:27-41

Widdows J, Friend PL, Bale A, Brinsley MD, Pope ND, Thompson CEL (2007) Inter-comparison between five devices for determining erodability of intertidal sediments. Cont Shelf Res 27:1174-1189

Widdows J, Pope ND, Brinsley MD (2008) Effect of Spartina anglica stems on near-bed hydrodynamics, sediment erodability and morphological changes on an intertidal mudflat. Mar Ecol Prog Ser 362:45-57

Submitted: July 29, 2008; Accepted: November 26, 2008

Proofs received from author(s): February 23, 2009 